lurynets, J., Belkin, M., and Belkin, L.

National Aviation University,

1, Cosmonaut Komarov Ave., Kyiv, 03680, Ukraine,

+380 44406 7901, iurynetsjulia@ukr.net

\title{
LEGAL PROTECTION OF COPYRIGHT AND RELATED RIGHTS IN UKRAINE IN THE CONTEXT OF INTERNATIONAL LAW
}

\begin{abstract}
Introduction. The development of the intellectual property law has been focused primarily on strengthening the protection of these rights. However, such enhanced protection leads to restrictions on the use of intellectual property. Therefore, it is necessary to find a proper balance.

Problem Statement. The issues of legal protection of copyright and related rights shall be considered by the national legislator taking into account the international regulations. At present, the world has created a ramified system of internatio $\neg$ nal acts in this area, including, in certain conflicting aspects that require comprehensive consideration and, at the same time, created opportunities for maneuvering between the different norms embodied in different acts. Therefore, certain aspects of the legal regulation of copyright and related rights under 9 key international acts (Berne Convention, Universal Copyright Convention, Treaty on the International Registration of Audiovisual Works, World Intellectual Property Organization (WIPO) - Treaty on Copyright Law and Performances and Phonograms, Rome Convention, Geneva Convention, Brussels Convention on the Distribution of Signals Carrying Programs Transmitted via Satellites, TRIPS Agreement) have been compared with each other and with the Ukrainian legislation in terms of optimization of legal regulation.

Purpose. To generalize international legal regulation of copyright and related rights and to compare it with the Uk $\neg$ rainian legal regulation.
\end{abstract}

Materials and Methods. The methods of documentary analysis and synthesis, comparative analysis, objective truth, etc. have been used.

Results. The legislation of Ukraine absolutizes the protection of copyright and related rights. In the context of the international discourse on the liberalization of restrictions on the use of intellectual property, the Ukrainian legal regulation does not fully comply with the modern international trends.

Conclusions. The absolutization of the protection of copyright and related rights does not automatically makes such protection consistent with the international standards. Recently, the world has developed an understanding of the need to harmonize the interests of authors (performers) with the interests of the society for access to the objects of these rights.

Keywords: copyright, related rights, exclusive right, and balance of interests.

As noted in Part 1 of Art. 27 of the Universal Declaration of Human Rights of December 10, 1948 , everyone has the right freely to participate in the cultural life of the community, to enjoy the arts and to share in scientific advancement and its benefits. At the same time in Part 2 of Art. 27 of this Declaration states that everyone has the

(C) IURYNETS, J., BELKIN, M., and BELKIN, L., 2019 right to the protection of the moral and material interests resulting from any scientific, literary or artistic production of which he is the author.

Pursuant to Part 1 of Art. 15 of the International Covenant on Economic, Social and Cultural Rights of 16.12.1966, the States Parties to the present Covenant recognize the right of everyone to benefit from the protection of the moral and material interests resulting from any scien- 
tific, literary or artistic production of which he is the author and, at the same time, to enjoy the benefits of scientific progress and its applications.

Thus, in the aspect of securing (protecting) the intellectual property rights, the two-pronged problem has been solved: protecting the intellectual property rights, on the one hand, and ensuring access of citizens and society as a whole to relevant works, objects of intellectual property, on the other hand.

In dissertation research [1], it was determined that in the European Union (EU) intellectual property law there is a shift in the balance of interests between the creator of the intellectual property object and the users of these objects for the sake of commercial users. V. Valle mentions the danger associated with the absolutization of intellectual property rights protection in Ukraine and with inadequate understanding of the role of these rights in the economic, social, and cultural development of the country $[2,5]$; the researcher notes that, in particular, the trend towards extending the copyright terms impairs the "public archive" of works due to the establishment of a longer period of their ownership in the status of private property, which limits the development of society's creative activity, science, and culture and, ultimately, violates human rights (in particular, the right to knowledge, freedom of speech, etc.) [2, 166]. The father of copyright, T. Jefferson, was afraid of this right turning into a monopoly of owners, provided its duration is long. This fear was justified [3]. Other experts have doubts about the usefulness of extending copyright in the context of access to copyright objects $[4,5]$. In this regard, it should be noted that in the citadel of the fight against "piracy" in the intellectual sphere, the United States, there is a flexible system of justifying the public interest in the use of work under the doctrine of "fair use". According to this doctrine, the courts have the right to recognize that certain actions regarding copyrighted works are legitimate, without waiting for amendments to the legislation. As a result, there is a way to accelerate the introduction of new technologies and the emergence of new devices and services [4]. Some issues of this have been also covered in [6-8].

It should be pointed out that even in specialized international acts on the protection of intellectual property rights, the need to balance the rights of authors (performers and producers) of a cultural work and the access of society to the relevant cultural property has been recognized. In the preamble to the World Intellectual Property Organization (WIPO) Copyright Treaty of 20.12.1996 and Performances and Phonograms Treaty, the need to keep a balance between the rights of authors (performers and producers) and the interests of the broad public, especially, in the field of education, research, and access to information. Art. 7 of the Trade-Related Aspects of Intellectual Property Rights Agreement (Annex 1C to the Agreement Establishing the World Trade Organization (WTO), (TRIPS)) states that the protection and enforcement of intellectual property rights should contribute to the promotion of technological innovation and to the transfer and dissemination of technology, to the mutual advantage of producers and users of technological knowledge and in a manner conducive to social and economic welfare, and to a balance of rights and obligations.

Therefore, this research that aims at overviewing the international copyright and related rights regulations and comparing them with the Ukrainian legislative framework in the context of finding a right balance between intellectual property rights protection and access to intellectual property, is timely and relevant.

The modern political, economic, and general civilizational development of Ukraine is marked with Europeanization that means convergence with Europe, its political, legal, technological, and cultural traditions. The legislative framework for such a rapprochement is the Agreement of 2014 between Ukraine, on the one hand, and the European Union, the European Atomic Energy Community, and their Member States, on the other hand (hereinafter, the Association Agreement). According to Part 1 of Art. 158 of the mentioned Agreement, the Parties shall ensure the adequate 
and effective implementation of the international treaties dealing with intellectual property to which they are parties, including the Agreement on Trade-related Aspects of Intellectual Property Rights, contained in Annex 1C to the WTO Agreement (hereinafter referred to as the "TRIPS Agreement"). Pursuant to Art. 161 of the Association Agreement, the Parties shall comply with: (a) Articles 1 to 22 of the International Convention for the Protection of Performers, Producers of Phonograms and Broadcasting Organizations (1961) (hereinafter referred to as the "Rome Convention"); (b) Articles 1 to 18 of the Berne Convention for the Protection of Literary and Artistic Works (1886, last amended in 1979) (hereinafter referred to as the "Berne Convention"); (c) Articles 1 to 14 of the World Intellectual Property Organization (hereinafter referred to as the 'WIPO') Copyright Treaty (1996) (hereinafter referred to as the "WCT"); and (d) Articles 1 to 23 of the WIPO Performances and Phonograms Treaty (1996).

It is important to note that while these international instruments regulate the principles of protection of copyright and related rights of humanitarian direction, they are also important in the field of science, engineering, and technology. Thus, even the Berne Convention (Part 1, Art. 2) states that the "literary and artistic works" shall include every production in the literary, scientific, and artistic domain, whatever may be the mode or form of its expression. The protection of computer programs and databases (the Copyright Treaty, Article 4, 5; the TRIPS Agreement, Article 10; the Association Agreement, Part 1, Article 180) was established referring to the provisions of the Berne Convention for the Protection of Literary and Artistic Works. The provisions of the above mentioned treaties concerning the need to balance the interests pay particular attention to the importance of these documents for science and technology. Therefore, the international acts discussed below are relevant not only for humanitarian culture, but also for science, technology, and computerization.
As stated in dissertation research [9], the existing system of legal protection of intellectual creative results started to develop recently. The first law on the protection of inventors was adopted in England as late as in 1623. Later, the so-called Statute of Queen Anne was passed in 1710. These acts were the first attempts to create a mechanism of legal protection of the creative results. Now, at the beginning of the 21st century, we can talk about the polysystemic legal protection of the intellectual activity results. As of today, a complex of international treaties concerning intellectual property has been developed, eight of which (the Berne Convention for the Protection of Literary and Artistic Works, the Universal Copyright Convention, the Treaty on the International Registration of Audiovisual Works (Film Register Treaty, FRT), the WIPO Treaties (the Copyright Treaty and the Performances and Phonograms Treaty), the Rome Convention for the Protection of Performers, Producers of Phonograms and Broadcasting Organizations, the Geneva Convention for the Protection of Producers of Phonograms Against Unauthorized Duplication of Their Phonograms, and the Brussels Convention Relating to the Distribution of Program-Carrying Signals Transmitted by Satellite) listed in review [10] plus the TRIPS Agreement not mentioned therein are binding on Ukraine as a member of the World Trade Organization (WTO) and the party to the Association Agreement. Moreover, the TRIPS Agreement obliges WTO Members to comply with the requirements of the Berne (Articles 1-21), Geneva, and Rome Conventions and the PP Treaty, even if they are not party to the relevant Conventions (Treaties). In its judgment of 26.04.2012, Case C-510/10, the Court of Justice, in particular, states [11] that the EU, although not being a party to the Berne Convention, is bound by its Articles 1-21, in accordance with the TRIPS Agreement to which the EU is a party. Those exceptions that are allowed for the parties to the said Conventions (Treaties) are also allowed for the WTO members, however, such a member shall give a 
notice thereof not only to the administrator (s) of the relevant Conventions (Treaties) but also to the TRIPS Council. Information about the above mentioned legal acts and their ratification (accession) by Ukraine is given in Table 1.

The Berne Convention provides legal protection for a large number of works in the field of literature, science, and the arts, including cinematographic and architectural works. As noted above, under the Berne Convention, protection is granted to computer programs and databases. Similar protection eligible objects are listed in Art. 433 of the Civil Code of Ukraine and in Art. 8 of the Law of Ukraine on Copyright and Related Rights (hereinafter referred to as the Law No. 3792-XII). Having compared them, one can see the compliance of the protection eligible objects as defined by the Ukrainian legislation with the Berne Convention [6, 266-268]. It should be noted that Ukraine has waived the right given by Part 2 of Art. 2 and Part 1 of Art. 2bis of the Berne Convention saying that it shall, however, be a matter for legislation in the countries of the Union to prescribe that works in general or any specified categories of works shall not be protected unless they have been fixed in some material form. Also, Ukraine has not refrained from the protection of political and judicial speeches, insofar as, under Part 1, Art. 433 of the Civil Code of Ukraine, lectures, speeches, sermons, and other oral works shall be eligible to protection and, under Part 2 of Art. 11 of Law No. 3792-XII, copyright for any work arises from the fact of its creation; the origin and exercise of copyright

Universal International Acts in the Sphere of Copyrights and Related Rights

Table 1

\begin{tabular}{|c|c|c|c|c|}
\hline Title & $\begin{array}{l}\text { Date of } \\
\text { ratification }\end{array}$ & Administrator & $\begin{array}{c}\text { Information about ratification } \\
\text { by Ukraine by virtue of respective } \\
\text { Law of Ukraine (LU) }\end{array}$ & $\begin{array}{l}\text { Validity as per } \\
\text { the Association } \\
\text { Agreement }\end{array}$ \\
\hline TRIPS Agreement & $\begin{array}{c}15.04 .1994 \\
\text { As revised } \\
06.12 .2005\end{array}$ & WTO & $\begin{array}{c}\text { LU No. } 250-\mathrm{VI} \\
\text { of } 10.04 .2008 \\
\text { (joining the WTO) }\end{array}$ & In force \\
\hline \multicolumn{5}{|c|}{ Copyright } \\
\hline $\begin{array}{l}\text { The Berne Convention for the Pro- } \\
\text { tection of Literary and Artistic Works }\end{array}$ & 24.07 .1971 & WIPO & $\begin{array}{c}\text { LU No. } 189 / 95-\mathrm{BP} \\
\text { of } 31.05 .1995\end{array}$ & In force \\
\hline $\begin{array}{l}\text { Universal Copyright Convention } \\
\text { (UCC), Paris }\end{array}$ & $\begin{array}{l}06.09 .1952, \\
\text { As revised } \\
24.07 .1971\end{array}$ & UNESCO & $\begin{array}{c}\text { Resolution of Verkhovna Rada } \\
\text { of Ukraine of 23.12.1993 } \\
\text { No. 3794-XII }\end{array}$ & - \\
\hline $\begin{array}{l}\text { Treaty on the International Regist- } \\
\text { ration of Audiovisual Works (Film } \\
\text { Register Treaty, FRT) }\end{array}$ & 18.04.1989 & WIPO & Has not been ratified & - \\
\hline WIPO Copyright Treaty (WCT) & 20.12.1996 & WIPO & $\begin{array}{l}\text { LU No. 2733-III } \\
\text { of } 20.09 .2001\end{array}$ & In force \\
\hline \multicolumn{5}{|c|}{ Related Rights } \\
\hline The Rome Convention & 26.10 .1961 & UNESCO & $\begin{array}{l}\text { LU No. 2730-III } \\
\text { of } 20.09 .2001\end{array}$ & In force \\
\hline The Geneva Convention & 29.10 .1971 & & $\begin{array}{l}\text { LU No. } 738-X I V \\
\text { of } 15.06 .1999\end{array}$ & - \\
\hline $\begin{array}{l}\text { WIPO Performances and Phonog- } \\
\text { rams Treaty (WPPT) }\end{array}$ & 20.12 .1996 & WIPO & $\begin{array}{c}\text { LU No. } 2732-\text { III } \\
\text { of } 20.09 .2001\end{array}$ & In force \\
\hline $\begin{array}{l}\text { The Brussels Convention Relating to } \\
\text { the Distribution of Program-Carrying } \\
\text { Signals Transmitted by Satellite }\end{array}$ & 21.05 .1974 & UNESCO & $\begin{array}{l}\text { USSR membership since } \\
20.01 .1989\end{array}$ & - \\
\hline
\end{tabular}


require neither the registration nor any other special design of the work, nor any other formalities.

The Berne Convention provides the following types of protection:

+ Authors of literary and artistic works protected by this Convention shall enjoy the exclusive right of making and of authorizing the translation of their works throughout the term of protection of their rights in the original works (Art. 8); the reproduction of these works, in any manner or form (Part 1 of Art. 9); the broadcasting of their works or the communication thereof to the public by any other means of wireless diffusion of signs, sounds or images; any communication to the public by wire or by rebroadcasting of the broadcast of the work, when this communication is made by an organization other than the original one; the public communication by loudspeaker or any other analogous instrument transmitting, by signs, sounds or images, the broadcast of the work (Part 1 of Article 11bis); the public recitation of their words, including such public recitation by any means or process; any communication to the public of the recitation of their works (Part 1 of Article 11ter); adaptations, arrangements and other alterations of their works (Art. 12); the cinematographic adaptation and reproduction of these works, and the distribution of the works thus adapted or reproduced; the public performance and communication to the public by wire of the works thus adapted or reproduced. (Art. 14);

+ Authors of dramatic, dramatico-musical and musical works shall enjoy the exclusive right of authorizing the public performance of their works, including such public performance by any means or process; any communication to the public of the performance of their works (Art. 11);

The WIPO Copyright Treaty (CT) additionally provides the following types of protection:

+ Computer programs are protected as literary works within the meaning of Article 2 of the Berne Convention. Such protection applies to computer programs, whatever may be the mode or form of their expression (Art. 4);

+ Authors of literary and artistic works shall enjoy the exclusive right of authorizing the making available to the public of the original and copies of their works through sale or other transfer of ownership (part 1 of Art. 6); any communication to the public of their works, by wire or wireless means, including the making available to the public of their works in such a way that members of the public may access these works from a place and at time individually chosen by them (Art. 8);

+ Authors of computer programs (in addition to those mentioned in Article 4), cinematographic works, and works embodied in phonograms, as determined in the national law of Contracting Parties shall enjoy the exclusive right of authorizing commercial rental to the public of the originals or copies of their works, except for, in the case of computer programs, where the program itself is not the essential object of the rental; and in the case of cinematographic works, unless such commercial rental has led to widespread copying of such works materially impairing the exclusive right of reproduction (Art. 7). The TRIPS Agreement repeats the provisions of Art. 4, 5, 6 of the WIPO Treaty (Part 1, Article 10, Part 2, Article 10, Article 11 of the TRIPS Agreement, respectively), but gives no additional protection to authors of literary and artistic works.

For comparison, in accordance with Part 3 of Art. 15 of Law No. 3792-XII, in Ukraine authors of works have the right to the following methods of copyright protection: to authorize or to prohibit: 1) reproduction of works; 2) public performance and public announcement of works; 3 ) demonstration and display to the public; 4) any republication of the works, if it is made by any organization other than the first publisher; 5) translations of works; 6 ) alterations, adaptations, arrangements and other similar modifications of works; 7 ) inclusion of works as components in collections, anthologies, encyclopedias, etc.; 8) first-sale dist- 
ribution of works, or alienation by other means or by hire or lease and by other transfer of title before the first sale of copies of the work; 9) presentation of their works to the public, so that its representatives can access the works from any place and at any time individually chosen by them; 10) the hire and/or commercial hire after the first sale, or alienation of the original or copies of audiovisual works by other means, computer programs, databases, musical works in the form of note pattern, as well as works recorded in a phonogram or videogram or in computer readable form; and 11) import of copies of works.

Having compared the listed types of legal protection with the abovementioned conventional ones makes it possible to conclude that in general, they are congruent. In particular, they distinguish the reproduction of works (par. 1), on the one hand, and the distribution of works (par. 8), on the other hand, as required by the Copyright Treaty (originally the Berne Convention protected the right to authorize or to prohibit the reproduction of works, without specifying the distribution).

At the same time, in some cases, Law No. 3792XII contains excessive measures that entail unreasonable restrictions on access, for example: (a) authorization from the copyright holder shall be obtained to incorporate works into collections, anthologies, encyclopedias, etc. (par. 7). There is no such requirement in the Berne Convention, the WIPO CT and TRIPS Agreements. Part 5 of Art. 2 of the Berne Convention contains a general requirement to respect the rights of such copyright holders, but there are no prohibitions on the reprinting of legally published works; b) the necessity of obtaining an authorization from the copyright holder for any re-publication of the works, for any organization other than the first publisher (par. 4) prescribed in such a way that it extends to the cases of notification not only by means of wired or wireless communication (Part 1, Article 11bis of the Berne Convention), but also in a printed manner; c) the necessity of obtaining an authorization from the copyright holder for com- mercial hire is absolutized (par. 10). There is no such restriction in the Berne Convention. For the first time, it appeared in the Copyright Treaty (Art. 7); later in almost the same form it was repeated in the TRIPS Agreement, and has been applying only to computer programs, cinematographic works, and works embodied in phonograms. At the same time, the commercial hire of cinematographic works is not limited, if done without making copies, the same applies to programs provided the program itself is not the main object of the hire; d) the necessity of obtaining an authorization from the copyright holder to translate works has been absolutized (par. 5). Indeed, the Berne Convention requires the copyright holder to be given the exclusive right to translate the work himself or to authorize the translation of his works (Art. 8). The UNESCO Convention (Paris, 24.07.1971) provides for the same guarantees (Part 1, Article 5), however Part 2, Article 5 states that any Contracting State may, by its domestic legislation, restrict the right of translation of writings, but only subject to certain provisions, that is, such guarantees are not unconditional. In this case, according to Art. 19 ibid., this Convention shall not abrogate multilateral or bilateral conventions or arrangements in effect between two or more Contracting States. In the event of any difference between the provisions of such existing conventions or arrangements and the provisions of this Convention, the provisions of this Convention shall prevail. Therefore, a national legislator may recede from the Berne Convention based on the UNESCO Convention.

Another element of copyright and related rights is the duration of protection. The time limits established in the various Conventions are given in Table 2.

The analysis has shown that Ukraine's legislation establishes the longest term of protection, the life of the author plus 70 years after his death, as compared with the life of author plus 50 years as per the Berne Convention (for cinematographic, photographic works and works of art, the protection term is allowed not to depend on the 
duration of author's life), and the life of the author plus 25 years after his death as per the UNESCO Convention. On the other hand, the TRIPS Agreement does not associate the term of protection with the lifetime of the author and establishes a term of 50 years from the date of the creation of the work (which is approximately the same as per the UNESCO Convention). Therefore, given the aforementioned priority of the UNESCO Convention, it is possible to set a shorter duration of copyright protection than that in Law No. 3792-XII, which will facilitate access of the humankind to the creative heritage.

With regard to the role of the Berne Convention in the protection of related rights, as stated in [12], the Rome Convention has not recognized the personal non-property rights of the performers. However, according to V. Valle [2, 121-122], before the adoption of the PPT, this gap was filled by Art. 6bis of the Berne Convention, according to which, independently of the author's economic rights, and even after the transfer of the said rights, the author shall have the right to claim authorship of the work and to object to any distortion, mutilation or other modification of, or other derogatory action in relation to, the said work, which would be prejudicial to his honor or reputation. Also, the Berne Convention (Art. 18) is important for the protection of related rights, inasmuch as according to the TRIPS Agreement (Part 6, Art. 14), the provisions of Art. 18 apply to related rights, as well.

Duration of Intellectual Property Protection under International Conventions

Table 2 and the Ukrainian Legislation

\begin{tabular}{|c|c|c|c|c|}
\hline The Berne Convention & $\begin{array}{c}\text { WIPO Copyright } \\
\text { Treaty }\end{array}$ & TRIPS Agreement & $\begin{array}{c}\text { UNESCO } \\
\text { Convention } \\
(\text { Paris, 24.07.1971) }\end{array}$ & $\begin{array}{l}\text { Law of Ukraine } \\
\text { No.3792-XII }\end{array}$ \\
\hline $\begin{array}{l}\text { Article } 7 \\
\text { (1) The term of protection } \\
\text { granted by this Convention } \\
\text { shall be the life of the author } \\
\text { and fifty years after his death. } \\
\text { (2) However, in the case of } \\
\text { cinematographic works, the } \\
\text { countries of the Union may } \\
\text { provide that the term of pro- } \\
\text { tection shall expire fifty years } \\
\text { after the work has been made } \\
\text { available to the public with the } \\
\text { consent of the author, or, fai- } \\
\text { ling such an event within fifty } \\
\text { years from the making of such } \\
\text { a work, fifty years after the ma- } \\
\text { king. (4) It shall be a matter } \\
\text { for legislation in the countries } \\
\text { of the Union to determine the } \\
\text { term of protection of photo- } \\
\text { graphic works and that of } \\
\text { works of applied art in so far as } \\
\text { they are protected as artistic } \\
\text { works; however, this term shall } \\
\text { last at least until the end of a } \\
\text { period of twenty-five years from } \\
\text { the making of such a work. }\end{array}$ & $\begin{array}{l}\text { Article } 9 \\
\text { Duration of the } \\
\text { Protection of } \\
\text { Photographic } \\
\text { Works } \\
\text { In respect of pho- } \\
\text { tographic works, } \\
\text { the Contracting } \\
\text { Parties shall not } \\
\text { apply the provi- } \\
\text { sions of Article } \\
\text { 7(4) of the Berne } \\
\text { Convention. }\end{array}$ & $\begin{array}{l}\text { Article } 12 \\
\text { Term of Protection } \\
\text { Whenever the term of } \\
\text { protection of a work, } \\
\text { other than a photo- } \\
\text { graphic work or a work } \\
\text { of applied art, is calcu- } \\
\text { lated on a basis other } \\
\text { than the life of a natu- } \\
\text { ral person, such term } \\
\text { shall be no less than } 50 \\
\text { years from the end of } \\
\text { the calendar year of au- } \\
\text { thorized publication, } \\
\text { or, failing such autho- } \\
\text { rized publication with- } \\
\text { in } 50 \text { years from the } \\
\text { making of the work, } 50 \\
\text { years from the end of } \\
\text { the calendar year of } \\
\text { making. }\end{array}$ & $\begin{array}{l}\text { Article IV } \\
\text { 2. a) The term of } \\
\text { protection gran- } \\
\text { ted by this Con- } \\
\text { vention shall be } \\
\text { the life of the aut- } \\
\text { hor and twenty } \\
\text { five years after his } \\
\text { death. }\end{array}$ & $\begin{array}{l}\text { Article } 28 \\
\text { Duration of Copyright } \\
\text { Protection } \\
\text { 1. The copyright for } \\
\text { work originates from } \\
\text { the fact of its creation } \\
\text { and takes effect from } \\
\text { the day of creation of } \\
\text { the work. } \\
\text { 2. The term of protec- } \\
\text { tion granted herewith } \\
\text { shall be the life of the } \\
\text { author and seventy } \\
\text { years after his death. }\end{array}$ \\
\hline
\end{tabular}


The Rome Convention was the first international act to provide legal protection to the three categories of related rights beneficiaries (performers, phonogram producers, and broadcasters). This Convention contains, among others, the definitions, the regulation of the terms of protection of related rights, the requirement to grant national protection to foreign beneficiaries, the types of protection, the necessity to comply with formalities for the recognition of related rights, and the limitation of related rights. The subsequently adopted Geneva Convention of 29.10.1971 in some respects extends and clarifies the Rome Convention concerning the producers of phonograms. Thus, according to the Geneva Convention, the distribution of phonograms means any act by which duplicates of a phonogram are offered, directly or indirectly, to the general public or any section thereof. Pursuant to the Geneva Convention, any duplicate of the phonogram shall bear the name of not only the performer, but also the phonogram producer. There are also some differences in the limitations of related rights.

The Rome Convention provides the following types of protection:

+ performers: the right to prevent unauthorized record, broadcast or communication of a performance to the public (except when the performance is broadcast or made using an authorized record), reproduction of the record provided the original audio record was unauthorized or unlawful;

+ producers of phonograms: the right to authorize or to prohibit any direct or indirect reproduction of their phonograms;

+ broadcasting organizations: the right to authorize or to prohibit: (a) re-transmission of their broadcasts; (b) record of their broadcasts; (c) reproduction of unauthorized or unlawful records of their TV broadcasts; (d) the communication of their TV broadcasts to the public, provided it is done in places accessible to the public for a fee.

The Geneva Convention does not introduce any additional types of related rights.
It should be noted that the right to broadcast under d) is not absolute, since national legislation may establish the specific conditions for broadcast.

The TRIPS Agreement (Art. 1-3, Art. 14) repeats the related rights set out in the Rome Convention. It also states (Article 14, par. 6) that any Member may, in relation to the rights conferred under paragraphs 1, 2 and 3, provide for conditions, limitations, exceptions and reservations to the extent permitted by the Rome Convention.

It is important to set the duration of the protection of related rights. Both the Rome Convention and the Geneva Convention (for phonogram producers) set a term of protection of 20 years. However, the TRIPS Agreement already extends the term of protection of the related rights of performers and producers of phonograms to 50 years. Therefore, WTO members have to revise their legislation in accordance with this requirement. This decision can hardly be considered prudent, since it breaks the balance between the interests of the right holder and the public and puts limitation on the latter's access to cultural property. In the case of the TRIPS Agreement, it should be acknowledged that, while the stricter protection of performers' rights can be considered more or less fair, since in this case it is a matter of putting into circulation records that the performer is not going to do (but such record may have historical value, and therefore, the term of protection of 50 years is fair), the protection for 50 years of commercially produced phonograms from which their right holders have already derived profit is unfair.

Like in the case of copyright, the Ukrainian legislator establishes excessive protection of related rights (part 3 of Article 44 of Law No. 3792-XII) by granting to broadcasting organizations a term of protection of 50 years. It should be noted even the PP Treaty developed giving a priority to the copyright subjects does not foresee so long duration of protection.

It is also important to study the cases where international treaties restrict related rights. Such 
restrictions are important in the context of the balancing the interests of the right holder and those who need access to cultural property. In this context, the Rome Convention allows (Article 15) Members to restrict the subject's related rights in certain special cases (use for personal purposes; use of short excerpts to report on current events; short-lived audio record by a broadcasting organization on its own device and for its own broadcasts; use solely for educational or research purposes) and, whatever the case may be, the same restrictions as are established by its national law and by-laws in the field of protection of copyright for works of literature and art. Once again, the TRIPS Agreement associates the right to impose restrictions on related rights solely with compliance with the requirements of the Rome Convention and does not provide for any other prohibitions on imposing such restrictions. Under such conditions, for example, according to Part 2 of Art. 9 of the Berne Convention, it shall be a matter for legislation in the countries of the Union to permit the reproduction of such works in certain special cases, provided that such reproduction does not conflict with a normal exploitation of the work and does not unreasonably prejudice the legitimate interests of the author. Art. 10 of this Convention states that it shall be permissible to make quotations from a work which has already been lawfully made available to the public, provided that their making is compatible with fair practice, and their extent does not exceed that justified by the purpose, including quotations from newspaper articles and periodicals in the form of press summaries. It shall be a matter for legislation in the countries of the Union, and for special agreements existing or to be concluded between them, to permit the utilization, to the extent justified by the purpose, of literary or artistic works by way of illustration in publications, broadcasts or sound or visual recordings for teaching, provided such utilization is compatible with fair practice.

Therefore, if the derogation from the copyright for literature and artistic works in these cases does not contravene the international obligations of the States, then the authorization to derogate from related rights will not be contrary to such obligations, as well. However, the Geneva Convention in this case states that the license shall be valid for duplication only within the territory of the Contracting State whose competent authority has granted the license and shall not extend to the export of duplicates (Art. 6 b).

Further, the protection of related rights of performers and producers of phonograms was strengthened by the PP Treaty. This Treaty is linked to the Rome Convention and the TRIPS Agreement [416, 121]. In general, the application of the Rome Convention is not obligatory for the party to the PP Treaty $[2,121]$ (of course, unless such a country is a party to the Rome Convention). The Treaty refers only to certain provisions of the Rome Convention and repeats its structure (in particular, Article 2 of the PP Treaty "Definitions" contains the definitions given in Article 3 of the Rome Convention; Article 3 of the Treaty on the national treatment complies with Article 4 of the Rome Convention and even defines by reference to the Rome Convention a list of persons to whom the principle of national treatment applies).

At the same time, in comparison with the Rome Convention, the PP Treaty introduces new provisions: the moral rights of performers (Art. 5 that develops Article 6bis of the Berne Convention) and new types of protection of non-property rights (Articles 9, 10, 12, 13, and 14); extends the term of protection of related rights of performers and producers of phonograms to 50 years, like the TRIPS Agreement; introduces the obligation of Contracting States to provide in their national laws adequate legal protection and effective legal remedies against the circumvention of effective technological measures that are used by performers or producers of phonograms in connection with the exercise of their rights under this Treaty, as well as against any distortion of electronic rights management information.

The PP Agreement additionally provides the following types of protection: a) performers: the 
exclusive right of authorizing the commercial rental to the public of the original and copies of their performances fixed in phonograms as determined in the national law of Contracting Parties (Art. 9); making available to the public of their performances fixed in phonograms, by wire or wireless means (Art. 10); b) to producers of phonograms: the exclusive right of authorizing the making available to the public of the original and copies of their phonograms through sale or other transfer of ownership (Art. 12); commercial rental (Art. 13); the making available to the public of their phonograms, by wire or wireless means (Art. 14).

The PP Treaty does not cover broadcasting organizations.

With regard to rental, it should be noted that the exclusive right of subjects of related rights to authorize the commercial rental of computer programsand/or phonograms has beenintroduced by the TRIPS Agreement (Art. 14 par. 4 in conjunction with Art. 11 par. 1). However, no such rights for performers have been established by the TRIPS Agreement.

Having compared the abovementioned norms of the international law in the field of related rights with the Ukrainian legislation, we summarize that: a) the basic law of Ukraine on the regulation of related rights is Law No. 3792-XII; b) there are no definitions such as "retransmission" and "broadcasting" in Law No. 3792-XII; they are given in the Law of Ukraine on Television and Radio Broadcasting; c) Law No. 3792-XII provides equal protection for both phonograms and videograms, although this is not required by the mentioned Conventions. Moreover, Art. 11 of the TRIPS Agreement expressly foresees a different of protection for video as compared with phonograms; (d) Law No. 3792-XII generally repeats the requirements of the PP Treaty and the TRIPS Agreement, but in some cases enhances the protection of related rights for the sake of their subjects. For example, in the PP Treaty, the right to impose restrictions on related rights similar to copyright restrictions on literary and artistic works is not conditioned by any circumstances. At the same time, Art. 42 of Law No. 3792-XII introduces additional conditions in this regard. While for phonograms these restrictions can be justified by the requirements of the Geneva Convention, for performances, videograms, and broadcasting programs they do not directly follow from the international treaties; e) Law No. 3792-XII introduces an extended term (50 years) for the protection of related rights of broadcasting organizations with respect to broadcasting programs, although such an obligation does not follow from any international agreement; f) par. e Part 1 of Art. 40 of Law No. 3792-XII provides for the exclusive right of subjects of related rights to authorize or to prohibit the import of phonograms, videograms, and their copies to the customs territory of Ukraine for the purpose of their distribution among the public. There is no international agreement to enforce such a right. If the phonogram is lawfully made abroad, the prohibition of its import to the customs territory of Ukraine breaches the principles of free trade (unless, of course, the essence of the record contradicts the rules on protection of public morals); g) the Ukrainian legislature has not restricted the right of broadcasting organizations to authorize or to prohibit other persons performing and displaying to the public their programs in places with paid access; g) Part 1 of Art. 25 of Law No. 3792-XII allows for reproducing works that have been previously lawfully published for personal or family purposes without author's authorization (or other copyright holder) and without the payment of royalties. However, according to Part 2 of Art. 25 and Part 2 of Art. 42 of Law No. 3792-XII, works and performances recorded in phonograms, videograms, their copies, as well as audiovisual works and their copies, may be reproduced at home solely for personal or for family purposes without authorization of authors, performers, phonogram producers, and videogame producers, however, the royalty shall be paid to the copyright holders. Therefore, if the international law allows for the establishment of uniform 
treatment of literary and artistic works, on the one hand, and performances, audiovisual works, and videograms, on the other hand, it is unreasonable to give a preference in the form of royalty payment in the second case even under the special procedure as per Part 4 of Art. 42 of Law No. 3792-XII.

In this regard, the authors of report [4] point out that serious problems in the field of related rights protection arise when people in their ordinary lives use content in ways that they believe cannot be prohibited in principle: sharing music files with their family. or copying a disc to listen to music in the car. There is an unjustified mismatch between the needs of the people and the rules of the law. However, it is difficult to explain them why they can freely give a friend a favorite book, but cannot do the same with regard to a digital book or music. In particular, the world-famous American Digital Millennium Copyright Act has been severely criticized in the world for running against consumers, scientists, and legal competitors rather than against intellectual pirates [13]. There is information that the U.S. Supreme Court is currently considering the unconstitutionality of the ban on copying copyrighted items using special software, since such a ban violates the freedom of expression and restricts the right of consumers to do what they want with things they have purchased [14].

Thus, the protection of intellectual property rights is associated with intricate relationships and conflicts with the access of mankind to the intellectual property. The excessive protection of intellectual property rights impedes the society's economic, scientific, technological, and cultural development of by restricting the development of creative activity of the society, science, and culture and, ultimately, violates human rights. Even specialized international acts on the protection of intellectual property rights recognize the need to find a sound balance. The overview of international legal regulation of copyright and related rights under the nine key international instruments (the Berne Convention for the Protection of Literary and Artistic Works, the Universal Copyright Convention, the Treaty on the International Registration of Audiovisual Works, the WIPO Copyright Treaty, the International Convention for the Protection of Performers, Producers of Phonograms and Broadcasting Organizations, the Geneva Convention for the Protection of Producers of Phonograms Against Unauthorized Duplication of Their Phonograms, the WIPO Performances and Phonograms Treaty, the Brussels Convention Relating to the Distribution of Program-Carrying Signals Transmitted by Satellite, and the TRIPS Agreement) has shown that the absolute protection of these rights does not automatically bring such protection to international standards. Recently, the world has perceived the need to balance the interests of copyright and related rights holders with the public interest in accessing the objects of those rights.

The comparison of the Ukrainian legislation with the international legal regulation has shown that in Ukraine the protection of copyright and related rights is absolutized at the legislative level. In the context of international discourse on the liberalization of restrictions on the use of intellectual property, there is reason to conclude that the Ukrainian regulation of copyright and related rights does not fully meet the current international trends. The prospects of the further research in this area is the development of amendments to the legislation in order to introduce the minimum standards of legal protection of intellectual property in accordance with the international legislative acts.

\section{REFERENCES}

1. Ennan, R. E. (2010). Pravove regulyuvannya vidnosin intelektualnoyi vlasnosti u evropeyskomu soyuzi. PhD (Law). Odesa [in Ukrainian]. 
2. Valle, V. (Potehina V. O.) (2010). Spadok Dzheymsa I ta korolevi Anni: ohorona intelektualnoyi vlasnosti u chasi y prostori. Kyiv: Duh i litera. URL: https://tiptiktak.com/b3b1f6b65376ba6732aaa75ae84ad75a54348.html (Last accessed: 10.09.2019).

3. Valle, V. (2012). Tvorchiy konflikt. Ukrayinskiy yurist, 5, 54-55 [in Ukrainian].

4. Avtoritetnyy obzor perspektiv prava intellektualnoy sobstvennosti v tsifrovoy sfere. Izlozheniye otcheta gruppy britanskikh ekspertov pod rukovodstvom professora I. Khargrivsa (Ian Hargreaves): Proyekt Lex Digital Blog. URL: http:// lexdigital.ru/2012/030/\#more-406 (Last accessed: 10.09.2019).

5. Komzyuk, L. T. (2012). Osnovni tendentsiyi garmonizatsiyi avtorskogo prava ES. Informatsiya i pravo, 1(4), 33-39 [in Ukrainian].

6. Yurinets, Yu. L. (2016). Evropeyizatsiya ukrayinskogo prava u sferi zabezpechennya kulturnih prav gromadyan: administrativno-pravoviy vimir. Uzhgorod: Vidavnitstvo FOP Sabov A.M.

7. Yurinets, Yu. L. (2012). Mizhnarodna sistema regulyuvannya sumizhnih prav v konteksti evropeyskoyi integratsiyi Ukrayini. Informatsiya i pravo, 3(6), 29-39 [in Ukrainian].

8. Yurinets, Yu. L. (2012). Mezhdunarodnaya sistema regulirovaniya smezhnykh prav v kontekste evropeyskoy integratsii Ukrainy. Materiály VIII mezinárodní vědecko-praktická konference «Vznik moderní vědecké - 2012». Díl 6. Právní vědy. Praha. Publishing House «Education and Science» s.r.o.

9. Abdullin, A. I. (2006). Pravo intellektualnoy sobstvennosti v Evropeyskom Soyuze: genezis, unifikatsiya, perspektivy razvitiya.PhD(Law). Moscow.URL:http://www.dslib.net/civil-pravo/pravo-intellektualnoj-sobstvennosti-v-evropejskomsojuze-genezis-unifikacija.html (Last accessed: 10.09.2019).

10. Germanova, O. G. Mizhnarodne regulyuvannya avtorskogo prava i sumizhnih prav u konteksti ukrayinskogo zakonodavstva. URL: http://journlib.univ.kiev.ua/index.php?act=article\&article=264 (Last accessed: 10.09.2019).

11. Sud Evrosoyuza o polnomochiyakh organizatsiy veshchaniya. o sootnoshenii evropeyskogo i natsionalnogo prava i printsipakh tolkovaniya. Proyekt Lex Digital Blog. URL: http://lexdigital.ru/2012/046/\#more-571 (Last accessed: 10.09.2019).

12. Sudarikov, S. A. (2000). Osnovy avtorskogo prava. Minsk: Amalfeya.

13. Unintended Consequences: Twelve Years under the DMCA. Electronic Frontier Foundation. March 3. 2010. URL: https://www.eff.org/wp/unintended-consequences-under-dmca (Last accessed: 10.09.2019).

14. Amerikanskiy Zakon ob avtorskom prave v tsifrovuyu epokhu osparivayut kak nekonstitutsionnyy. REPLYUA. 24.07.2016. URL: http://replyua.net/news/politika-v-mire/34872-amerikanskiy-zakon-ob-avtorskom-prave-v-cifrovuyuepohu-osparivayut-kak-nekonstitucionnyy.html (Last accessed: 10.09.2019).

Received 22.12.18

Revised 06.03.19

Accepted 18.03.19

\section{Ю.Л. Юринець, М.Л. Бєлкін, Л.М. Бєлкін \\ Національний авіаційний університет \\ просп. Космонавта Комарова, 1, 03680, Київ, Україна, +380 44406 7901, iurynetsjulia@ukr.net \\ ПРАВОВА ОХОРОНА АВТОРСЬКОГО ПРАВА \\ І СУМІЖНИХ ПРАВ В УКРАЇНІ В КОНТЕКСТІ МІЖНАРОДНОГО ПРАВА}

Вступ. Розвиток права інтелектуальної власності рухався переважно у напрямку посилення захисту цих прав. Однак це призводить до обмеження використання об'єктів інтелектуальної власності. Отже, необхідним є пошук належного балансу між інтересами володільців та суспільства.

Проблематика. Питання правової охорони авторського права і суміжних прав національний законодавець повинен вирішувати з урахуванням міжнародного регулювання. На сьогодні у світі створено розгалужену систему міжнародних актів у цій галузі, зокрема й в окремих суперечливих аспектах, які потребують комплексного підходу, створюючи при цьому можливості маневрування між різними нормами, втіленими у різних актах. Тому порівняння окремих аспектів правового регулювання авторського права і суміжних прав за 9 ключовими міжнародними актами у цій галузі (Бернська конвенція, Всесвітня конвенція про авторське право, Договір про міжнародну реєстрацію аудіовізуальних творів, Договори Всесвітньої організації інтелектуальної власності (ВОІВ) - про авторське право та про виконання і фонограми, Римська конвенція, Женевська конвенція, Брюссельська конвенція про поширення 
сигналів, що несуть програми, які передаються через супутники, Угода TRIPS) між собою та з українським законодавством $є$ актуальним з точки зору оптимізації правового регулювання.

Мета. Узагальнення міжнародного правового регулювання авторських і суміжних прав та порівняння його з українським правовим регулюванням.

Матеріали й методи. Застосовано методи документального аналізу й синтезу, порівняльного аналізу, об’єктивної істини та ін.

Результати. В законодавстві України абсолютизується охорона авторського права і суміжних прав. У контексті міжнародного дискурсу щодо лібералізації обмежень на використання об'єктів інтелектуальної власності українське правове регулювання не повною мірою відповідає сучасним міжнародним тенденціям.

Висновки. Абсолютизація захисту авторських і суміжних прав не означає автоматичного приведення такого захисту до міжнародних стандартів. Останнім часом у світі склалося розуміння необхідності гармонізації інтересів авторів (виконавців) з інтересами суспільства на доступ до об’єктів цих прав.

Ключові слова: авторське право, суміжні права, виключне право, баланс інтересів.

\author{
Ю.Л. Юринец, М.Л. Белкин, Л.М. Белкин \\ Национальный авиационный университет \\ просп. Космонавта Комарова, 1, Киев, 03680, Украина, \\ +380444067901, iurynetsjulia@ukr.net \\ ПРАВОВАЯ ОХРАНА АВТОРСКОГО ПРАВА \\ И СМЕЖНЫХ ПРАВ В УКРАИНЕ В КОНТЕКСТЕ \\ МЕЖДУНАРОДНОГО ПРАВА
}

Введение. Развитие права интеллектуальной собственности двигалось преимущественно в направлении усиления защиты этих прав. Однако такое усиление защиты приводит к ограничению использования объектов интеллектуальной собственности. Следовательно, необходим поиск надлежащего баланса между интересами владельцев и общества.

Проблематика. Вопросы правовой охраны авторского права и смежных прав национальный законодатель должен решать с учетом международного регулирования. На сегодня в мире создана разветвленная система международных актов в этой области, в том числе и в отдельных противоречивых аспектах, которые требуют комплексного подхода, создавая при этом возможности маневрирования между различными нормами, воплощенными в разных актах. Поэтому сравнение отдельных аспектов правового регулирования авторского права и смежных прав по 9 ключевым международным актам в этой области (Бернская конвенция, Всемирная конвенция об авторском праве, Договор о международной регистрации аудиовизуальных произведений, Договора Всемирной организации интеллектуальной собственности (ВОИС) - об авторском праве и по исполнениям и фонограммам, Римская конвенция, Женевская конвенция, Брюссельская конвенция о распространении сигналов, несущих программы, передаваемые через спутники, Соглашение TRIPS) между собой и с украинским законодательством является акутальным с точки зрения оптимизации правового регулирования.

Цель. Обобщение международного правового регулирования авторских и смежных прав и сравнение его с украинским правовым регулированием.

Материалы и методы. Применены методы документального анализа и синтеза, сравнительного анализа, объективной истины и др.

Результаты. В законодательстве Украины абсолютизируется охрана авторского права и смежных прав. В контексте международного дискурса по либерализации ограничений на использование объектов интеллектуальной собственности украинское правовое регулирование не в полной мере соответствует современным международным тенденциям.

Выводы. Абсолютизация защиты авторских и смежных прав не означает автоматического приведения такой защиты к международным стандартам. В последнее время в мире сложилось понимание необходимости гармонизации интересов авторов (исполнителей) с интересами общества на доступ к объектам этих прав.

Ключевые слова: авторское право, смежные права, исключительное право, баланс интересов. 